\title{
Mistérios do Rio de Janeiro: em torno das Memórias de um sargento de milícias e seu público
}

\author{
The Mysteries of Rio de Janeiro: notes on Memoirs of a Militia \\ Sergeant and its readers
}

Jefferson Cano ${ }^{1}$

\section{RESUMO}

A representação fiel dos costumes no Brasil imperial é, em geral, a principal característica atribuída a este romance pelos estudiosos. Considerando a hipótese de um horizonte de expectativas comum a uma grande parcela de leitores do Rio de Janeiro de meados do século XIX, este artigo sugere a existência de outros significados relacionados ao romance e partilhados por seus primeiros leitores. Além da reprodução realista de personagens e situações típicas, a narrativa ofereceu também uma representação apaziguada da vida social, distante das tensões e contradições que deram sentido à experiência política de seus leitores.

Palavras-chave: Literatura Brasileira - Século XIX; Romance; Memórias de um sargento de milícias; Leitores.

\section{ABSTRACT}

Scholars has generally recognized the faithful representation of the customs of imperial Brazil as a main feature of the novel Memórias de um sargento de milícias. Considering the hypothesis of a horizon of expectations common to a wide range of readers in the mid-nineteenth century Rio de Janeiro, this article suggests the existence of other meanings related to the novel and shared by its early readers. Besides the realistic reproduction of typical characters and situations, the story also presented an appeased representation of social life, far from the tensions and contradictions that gave sense to the political experience of its readers.

Keyword: Brazilian Literature - XIXth. Century; Novel; Memoirs of a Militia Sergeant; Readers.

1 Doutor em História e professor do Departamento de Teoria Literária da UNICAMP. 
1.

Entre 1854 e 1855 publicaram-se os dois volumes assinados por "Um Brasileiro" e intitulados Memórias de um sargento de milícias, romance que fora antes publicado semanalmente e sem qualquer indicação de autoria no Correio Mercantil, entre junho de 1852 e julho de 1853. Apesar de intitular-se Memórias, o relato não se apresentava em formato propriamente memorialístico, visto ser uma história narrada em terceira pessoa, e não pelo próprio sujeito da vida rememorada. A vida em questão era a de Leonardo, filho de Leonardo Pataca, que de maneira muito sucinta, poderia ser resumida com as palavras emprestadas de um de seus leitores mais entusiasmados em fins do século XIX, José Veríssimo:

O enredo, entrecho ou fundo do romance de Manuel d'Almeida, é a desinteressante história de um menino travesso e rapaz extravagante e quase perdido no Rio de Janeiro do princípio deste século. Justamente quando esse menino, cujas travessuras ou maldades, como diziam as bem desenhadas velhas que com ele houveram de tratar, ocupam duas boas partes do livro, se faz homem e é feito sargento de milícias, o romance acaba, deixando injustificado o título, que devia ser antes 'memórias de um menino que foi sargento de milícias'. (VERÍSSIMO, 1978, p. 294).

É verdade que o resumo não parece fazer jus ao entusiasmo - nem por isso menos sincero - de quem considerava as Memórias de um sargento de milícias um romance que "para ser um dos mais belos da nossa literatura, só lhe falta ser bem escrito" (VERÍSSIMO, 1978, p. 296). Supondo não haver qualquer ironia no juízo - como garante o crítico - estamos então diante de uma questão que se tornará central ao destino desse livro junto à crítica: a consagração de um romance cujo mérito literário se encontra em outra parte que não em sua própria realização enquanto romance. Nesse texto partimos dessa questão para traçarmos em linhas gerais o nosso objetivo, que será o de indagar dos significados que estiveram associados ao romance, bem como daqueles que ficaram soterrados junto às possibilidades de recepção de seus primeiros leitores. Nesse sentido, trata-se de um exercício de interpretação do texto literário que tem como problema central a sua relação com o leitor, questão que parecia apresentar-se ao próprio Almeida, quando ele tratava de publicar em livro o seu romance.

De fato, entre a versão publicada pela imprensa e a que saiu em livro, a mais substancial alteração encontrava-se no epílogo, onde o leitor do jornal encontrava uma despedida e um apelo pela indulgência do leitor, junto à modesta avaliação que o autor fazia de seu trabalho: 
Daqui para diante começa a aparecer o reverso da medalha de todas essas chocarrices de que até então constou a vida do Sargento; vinha a morte de D. Maria, a morte do velho Leonardo Pataca, e mil outras cousas tristes. $\mathrm{O}$ autor não tem gênio para tratar dessas cousas, e por isso dá fim pedindo que se esqueçam do seu trabalho, não lhe façam carga dos seus defeitos, porque foi apenas um ensaio. Se alguém disser que é mau costume querer o barbeiro novo aprender na barba do freguês tolo; ele observara que os leitores e só deles se hão de aproveitar de algum ponto bom que por ventura este ensaio possa dar, e que portanto tenham tolerância para quem principia. (Correio Mercantil, 31 de julho de1853).

Já o leitor do romance em volume encontraria um ponto final mais lacônico e até algo abrupto: "Daqui em diante aparece o reverso da medalha. Seguiu-se a morte de D. Maria, a do Leonardo Pataca, e uma enfiada de acontecimentos tristes que pouparemos aos leitores, fazendo aqui ponto final" (UM BRASILEIRO, 1855, p. 159). Se para o autor fazia-se necessária a mudança no texto ao mudar o seu suporte (talvez porque não haveria razão para pedir aos seus leitores o esquecimento de seu romance, justamente quando este deixava a efemeridade do jornal para ser reeditado em livro), para a discussão que se propõe a seguir ela indica um rumo a seguir e uma hipótese de trabalho, de que a produção de sentidos por parte do leitor se dá em consonância com as condições de publicação da obra literária. Dessa maneira, tentaremos discutir até que ponto a publicação de uma obra literária em diferentes meios instituía experiências específicas de leitura e de escrita.

A questão certamente não é nova, não faltando resultados de pesquisas que já permitem uma resposta positiva. Nesse caso, cabe, antes de tudo, questionar a naturalidade com que a encaramos, reconhecendo as incertezas e insuficiências do caminho escolhido. Afinal, ao estabelecermos a especificidade da experiência do leitor em cada meio de publicação, corremos o risco de construir um leitor desprovido de subjetividade, que só existe em função de um veículo específico e só reage a ele; pelo contrário, seria muito razoável supor que o leitor de jornais é o mesmo que lê livros, ou, ainda mais razoável, que o leitor de romances em jornais é o mesmo que lê romances em livros e que o conjunto da experiência do sujeito é mobilizado tanto em uma situação quanto em outra para a construção de significados. Além disso, a sobrevalorização das condições de publicação da obra corre também o risco de construir um leitor fragmentado, circunscrito àquela experiência específica de leitura, quando, na verdade, o leitor empírico que se depara com uma obra em determinadas condições não se formou como leitor na sincronia recortada daquela publicação; ele carrega consigo uma experiência prévia, impossível de ser positivamente definida, mas inseparável da produção de sentidos. Por fim, não podemos (nem devemos) nos livrar da lembrança incômoda de que, mesmo que pudéssemos definir positivamente a experiência de um leitor - seja um sujeito empírico ou idealizado, individual ou coletivo - 
jamais poderíamos dar como certo que a experiência se refletisse necessariamente na expectativa desse leitor diante da obra, a partir da qual ele a lê e compreende. O jogo possível entre experiência e expectativa é o que dá corpo à leitura das Memórias de um sargento de milícias e seu entorno (e talvez mais deste que daquela) que se apresenta a seguir.

\section{2.}

A diferença que se estabelecia na relação entre autor e leitor em cada versão publicada do romance em cada suporte permite supor uma especificidade que constitui a experiência (tanto do autor como de seu público) engendrada pelo folhetim, na qual entram em jogo aspectos da história narrada que talvez fossem fundamentais para a atribuição de significados pelo leitor e para os quais podia ser decisiva a fragmentação da escrita e da leitura.

No caso de Memórias de um sargento de milícias, a dispersão ao longo de treze meses de publicação no jornal talvez fosse o elemento que possibilitava a proliferação de detalhes que revelavam algum descuido do autor, ou mesmo certo esquecimento, que podia também ser compartilhado com o leitor. Esse eventual esquecimento era ainda favorecido por uma narrativa razoavelmente aberta, à qual iam se juntando personagens ao longo do tempo, conforme a ação se desdobrava. Na verdade, os personagens que aparecem nas Memórias de um sargento de milícias cumprem funções muito específicas na narrativa, as quais delimitam também a sua elaboração. Alguns deles têm sua existência restrita ao presente da ação de que participam, compondo apenas um dos fragmentos da narrativa: a vizinha, por exemplo, que serve para compor algumas cenas importantes da infância de Leonardo, deixa de ser mencionada e não faz falta, não merecendo do narrador qualquer explicação sobre o seu destino; o mesmo pode ser dito da namorada Vidinha, igualmente desaparecida, enquanto Maria Regalada, ao contrário, aparece no romance repentinamente, só para proporcionar o seu final feliz.

Isso não significa, porém, que no núcleo de personagens centrais à história haja maior cuidado do autor, pois mesmo aí parece que encontramos as marcas da escrita e da publicação seriadas. Somente doze semanas após o início da publicação o leitor fica sabendo que "a comadre tinha uma sobrinha que vivia em sua companhia, e que lhe pesava sofrivelmente sobre as costas" (Correio Mercantil, 19 de setembro de 1852), informação que é apresentada junto ao fato de que a comadre tinha a intenção de casar Leonardo Pataca com sua sobrinha. Um mês depois, sabe-se que "a comadre tinha conseguido o seu fim, pelo que diz respeito à sobrinha" (Correio Mercantil, 11 de outubro de 1852), embora não importe dizer como ou quando isso aconteceu. Passados cerca de dois meses, quando o casal passa de fato a interessar à ação do romance, a tal sobrinha ganha um nome, porém muda de parentesco, aparecendo como filha da comadre: 
Os leitores devem estar lembrados de que o nosso antigo conhecido, de quem por algum tempo nos temos esquecido, o Leonardo-pataca, apertara-se em laços amorosos com a filha da comadre, e que com ela vivia em santa e honesta paz. Pois esse viver santo e honesto deu em tempo oportuno o seu resultado. Chiquinha (era este o nome da filha da comadre) achou-se de esperanças e pronta a dar à luz. (Correio Mercantil, 05 de dezembro de 1852).

Quando, um mês depois, já acabara a paz doméstica no lar do meirinho, o autor se referia novamente à filha da comadre, como se informasse aos leitores pela primeira vez o nome da personagem, mas se confundia ao dizer que "Mariquinhas (tal era o nome da filha da comadre, amante do Leonardo-pataca) começou a embirrar com o seu filho adotivo" (Correio Mercantil, 09 de janeiro de 1853). Detalhes como esses, que escapavam ao autor e possivelmente também ao leitor do jornal, ganham visibilidade em uma leitura sob o formato de livro, mas não chegam a comprometer a estrutura da narrativa; o mesmo, porém, não pode ser dito de outros dados, que davam origem a inconsistências mais sérias. A principal dessas talvez fosse introduzida pela descrição de Leonardo Pataca que era fornecida no primeiro capítulo do romance:

Chamavam assim a uma rotunda e gordíssima personagem de cabelos brancos e carão avermelhado, que era o decano da corporação, o mais antigo dos meirinhos que viviam nesse tempo. A velhice o tinha tornado moleirão e pachorrento; com sua vagareza atrasava o negócio das partes; não o procuravam; e por isso jamais saía da esquina: passava ali os dias sentado na sua cadeira, com as pernas estendidas e o queixo apoiado sobre uma grossa bengala, que depois dos 60 era sua infalível companhia. Do hábito que tinha de queixar-se constantemente de que só pagassem por sua citação a módica quantia de 320 réis lhe viera o apelido que juntavam ao seu nome. (Correio Mercantil, 27 de junho de1852).

Um mês depois, o meirinho moleirão sem clientela já aparecia de outra maneira, pois, ao ser preso pelo temido major Vidigal, "aparentemente os companheiros mostraram-se sentidos, porém secretamente não deixaram de estimar o contratempo, porque o Leonardo era muito afreguesado, e enquanto estava ele preso as partes os procuravam" (Correio Mercantil, 25 de julho de 1852). Antes dessa contradição, porém, a primeira inconsistência já surgira junto com a apresentação do personagem. Segundo se lia no primeiro capítulo publicado, Leonardo fora algibebe em Lisboa e viera ao Brasil após se aborrecer do negócio, conseguindo aqui o emprego de meirinho, que exercia "desde tempos remotos". Sabendo-se ainda que, quando de sua vinda, Leonardo "não era nesse tempo de sua mocidade mal apessoado", abre-se necessariamente um largo intervalo temporal, entre a mocidade de 
Leonardo, tempo de sua vinda ao Brasil, e sua velhice, marco inicial da narrativa, o que coloca uma questão sobre o entendimento que podemos dar ao "Era no tempo do rei", que abre o romance.

Afinal, o que exatamente "era" no tempo do rei? Toda a ação narrada ou apenas o seu início? A resposta seria desnecessária para o leitor do jornal, que encontrava o primeiro capítulo do romance precedido de uma introdução em que o autor-jornalista anunciava sua obra, "dando princípio à publicação de uma história que não deixa de ser longa, por ter tido o seu princípio no tempo do rei, e acabar no em que nos achamos" (Correio Mercantil, 27 de junho de 1852). Assim, se o romance se abria no jornal como uma história que ia do tempo do rei ao presente da publicação, a publicação em livro, eliminando esse exórdio, eliminava também uma chave de leitura importante para dar significado à história. Porém, mesmo a ideia de que era possível identificar algumas características do tempo do rei ao seu próprio tempo devia contar com um leitor pouco rigoroso em suas expectativas quanto ao enredo de um romance que, ao longo das semanas, introduzia elementos que, cada vez mais, embaraçavam o fio da meada.

Ainda no que se refere ao primeiro personagem apresentado, Leonardo Pataca, o que se diz a princípio é apenas que ele exercia a profissão desde tempos remotos, sem precisar o momento de sua vinda ao Brasil, localizada apenas em sua mocidade. Essa imprecisão permitia que Leonardo chegasse da mocidade à velhice antes de se abrir o romance, momento em que, com mais de sessenta anos, era "o mais antigo dos meirinhos que viviam nesse tempo". Quando, porém, seis semanas mais tarde, o autor estreitava as relações entre seus personagens, tornava-se ainda mais complicada a linha temporal da história. Sendo Leonardo preso pelo major Vidigal, a comadre recorre à influência de um velho tenentecoronel, que se interessa pela causa do meirinho em um capítulo apropriadamente chamado "Explicações". Tivera o velho em Portugal um filho desordeiro e jogador que desonrara uma certa Mariazinha, cuja mãe o procurou poucos dias antes que ele embarcasse "para o Brasil em companhia d'elrei" para cobrar-lhe o casamento, o que acaba sendo trocado por um dote:

Deste modo ficou o caso um pouco remediado, posto que a consciência do capitão, que era de homem de honra, não ficara de modo algum satisfeita. $O$ tempo porém não dava lugar a mais; era chegado o momento de acompanhar a el-rei, e ele partiu deixando o filho recomendado a quantos amigos tinha. Decorreram os anos, e quando menos esperava soube que se achava no Rio de Janeiro em companhia do Leonardo a tal Mariquinhas, que então já era a Maria que os leitores bem conhecem. Procurou fazer o que pudesse por ela para satisfazer todos os seus escrúpulos de pai honrado, porém quis fazê-lo ocultamente. Foi ter com a comadre, a quem já conhecia, e a encarregou de o avisar apenas sentisse que a Maria sofria qualquer necessidade. (Correio Mercantil, 08 de agosto de 1852). 
Dessa maneira, o encontro de Leonardo e Maria das Hortaliças, com seus respectivos pisadela e beliscão a bordo do navio que os trouxera ambos ao Brasil, não podia ter se dado antes da partida de D. João e sua corte, da qual fazia parte o velho tenente coronel. Portanto, "no tempo do rei" Leonardo Pataca não podia ser meirinho "desde tempos remotos", e nem mesmo poderia o tempo de sua mocidade ser mais remoto que esse tempo do rei, o que criava sérias dificuldades para a história. Afinal, tendo Maria das Hortaliças embarcado após o rei e começado a sentir certos enojos assim que desembarcou, seu filho Leonardo teria nascido em algum momento a partir de 1808; como ao fim da história ele tem cerca de vinte anos, e como ao seu final feliz segue-se a morte do Leonardo pai, nessa linha do tempo o Pataca não podia ter chegado da mocidade aos 60 anos (ou mesmo aos 50, como diria a versão publicada em livro). Por outro lado, esse intervalo de cerca de vinte anos que contém a vida do Leonardo filho não cabia no tempo do rei, não sendo tampouco suficiente para chegar daquele tempo ao presente da publicação, como anunciava o exórdio do primeiro capítulo no jornal, que se mostrava então uma chave de leitura inútil.

A constatação de que os personagens de pai e filho são construídos de maneira incongruente, assim como a própria cronologia da narrativa, torna-se significativa na medida em que nos revela as condições de produção e de consumo dessa literatura. A essa altura, porém, uma reflexão sobre essas condições, que acaba sendo também sobre a própria relação que se estabelece entre literatura e imprensa no período, exige que deixemos de lado o atalho fácil de concluir apenas pela pressa da escrita para um público pouco exigente, que resultaria tanto no descuido da forma quanto na desatenção da leitura. Afinal, para além de todos os senões que possamos levantar à construção dos personagens e do enredo pelo redator do Correio Mercantil, esse trabalho só nos leva a outro problema que se impõe à nossa leitura a partir daqui: deixado o formato de folhetim pela publicação em volume, nem por isso o livro foi desmerecido pela crítica; a princípio apenas ignorado, seria depois definitivamente canonizado. O próximo passo, então, será tentar reconstituir as expectativas em relação ao romance e o referencial crítico que podiam informar tanto o autor quanto seus leitores.

\section{3.}

Na medida em que o próprio narrador do romance indicava suas referências literárias, tornava acessível ao leitor um significado que podia estar presente igualmente no jornal ou no livro. Nesse sentido, uma peça importante do discurso do narrador sobre o próprio romance se encontrava nas passagens que permitiam entender como ele se situava diante da literatura contemporânea. Essa atitude do narrador inseria o romance dentro de uma série literária, que podia assumir um significado específico para o consumidor de literatura por meio da imprensa, o qual se tornava inacessível em uma leitura descolada do suporte 
original. Nesse caso, a questão é colocada pelo parágrafo introdutório do redator que precedia a publicação do segundo capítulo das Memórias no jornal:

\begin{abstract}
Nesta ocasião entregou-nos o Sr. Gregório uma carta, e dentro dela encontramos a continuação das - MEMÓRIAS DE UM SARGENTO DE MILÍCIAS. - Diz-nos o correspondente que já tem escrito nove capítulos, e que se Deus lhe der vida e paciência, irá ainda mais longe, e tem plano formado para uns - MISTÉRIOS DO RIO DE JANEIRO, - obra em que se empenha conquanto não afiance a perfeição, e muito menos conclusão, razão porque preferiu dar-lhe tal título. (Correio Mercantil, 04 de julho de 1852).
\end{abstract}

Ao leitor do Correio Mercantil, devia ser clara a ironia, ou, pelo menos, assim devia esperar o redator. Sinalizando que esse romance dialogava com outras obras do mesmo gênero, ele contaria com certo domínio por parte do leitor de um conjunto de referências que davam sentido aos recursos empregados para se situar nesse contexto. E um desses recursos encontrava-se no parágrafo acima, que apresentava o autor das Memórias como autor de uns Mistérios do Rio de Janeiro. Quando o próprio Correio interrompia a publicação dos Mistérios do Povo, de Eugène Sue, para anunciar a venda em fascículo de seu décimo quinto caderno (Correio Mercantil, 26 de junho de1852), esse folhetim já devia parecer interminável, justificando a brincadeira com a obra que o autor não garantia concluir. Por outro lado, parodiando um título em moda, ele aproveitava para ironizar, com o duvidoso sucesso que ele próprio poderia atingir, o sucesso dessas obras às quais se referia.

Além do folhetim de Sue que então se publicava, o Correio anunciava a venda na sua tipografia dos dez volumes dos Mistérios de Londres, de Paul Féval, por $4 \$ 000$ (Correio Mercantil, 26 de junho de 1852); talvez isso seja indício do sucesso de uma fórmula folhetinesca, ou talvez sintoma de seu desgaste, visto que a mesma obra em dez volumes era anunciada no mesmo jornal quatro anos antes pelo dobro do preço, saindo cada volume avulso por $1 \$ 000$ (Correio Mercantil, 02 de janeiro de 1848). Assim, logo no segundo dia de publicação das Memórias, o jornal sugeria a filiação do seu folhetim a toda uma linhagem, identificada ao sucesso de Eugène Sue, ao mesmo tempo em que mantinha o tom de ironia que lhe garantia certo distanciamento do mesmo, o que devia ser também conveniente, visto que o sucesso do autor francês revelava em seu reverso as tensões envolvidas na difusão da literatura pela imprensa.

Circulando desde 1848 como órgão de um grupo ligado ao partido liberal, o Correio Mercantil traria naquele mesmo ano um artigo traduzido do francês, reproduzido de seu correligionário Diário Novo, que saía no Recife. O jornal pernambucano não informava a origem do texto, que vinha assinado apenas por Evaristo, tendo sido traduzido por I. V. Pimenta de Carvalho. O Correio Mercantil omitiu o nome do tradutor e acrescentou um 
título - "O Folhetim" - ao artigo, que saíra no Diário Novo apenas com a rubrica "Variedade". Nesse artigo, o crítico francês carregava no tom trágico com que lamentava a morte da literatura, provocada pelo folhetim:

\begin{abstract}
Maldito seja três vezes em nome da arte e da poesia o primeiro que se lembrou de publicar em folhetim as obras de imaginação! Pode dizer-se que deu um golpe mortal na literatura, que assassinou esta cousa encantadora, que em outro tempo se chamava um livro, e que hoje somente é a reprodução e fraude dos periódicos. Ele assassinou também aquilo que se chamava biblioteca, e que no tempo de agora não é senão uma superfetação, um eco baixo dos periodistas. (Correio Mercantil, 09 de outubro de 1848).
\end{abstract}

A qualidade literária da obra publicada era, para esse articulista, um dado indissociável da prática de leitura instituída pelo folhetim. A leitura de um romance no "fundo de um bosque", em meio à emoção de descobrir suas "páginas virginais, cheias de divino mistério", fora perdida pelo advento da leitura de folhetins, que se assemelhava a "uma prostituta que nada mais tem que dar nem que descobrir, e cujo cinto antes de aproximar-se de vós fora desatado por mil mãos profanadoras em todas as encruzilhadas, e em todas as tabernas". Assim, mesmo admitindo-se a possibilidade de um periódico querer publicar "primores de obra", não as encontraria, porque o folhetim era "o modo de publicação mais absurdo, mais inepto e fatal", afastando de si qualquer "belo engenho" que desejasse ver sua obra lida "pia e santamente". Mesmo livros como Atalá, Paulo e Virgínia ou $O$ vigário de Wakefield, não fariam o mesmo efeito se publicados no espaço do jornal. De qualquer modo, a menção a títulos como esses nos permitem perceber a expectativa quanto ao que seria uma exceção que o crítico buscava em meio aos folhetins, "que há perto de dez anos não dão há luz senão romances e novelas". Sob o império do periódico, o gênero se transformara, afastando-se daqueles modelos de décadas passadas, não se encontrando desde então uma "ficção honesta, compilada com amor verdadeiramente literário":

Desde o dia em que foi preciso encher sem sossego nem trégua este antro devorador, este sorvedouro sem fundo, este tonel das Danaides, acabou-se o culto desinteressado das letras. É desde então que a inspiração cedeu lugar à indústria, e que a arte se extinguiu em presença do comércio. (Correio Mercantil, 09 de outubro de 1848).

Evaristo ecoava ainda o tema e os termos com que, há quase dez anos, Sainte-Beuve denunciara a "literatura industrial" (SAINTE-BEUVE, 1839). Mas não se tratava apenas do interesse que guiava o escritor e substituía a arte; o fato é que esse comércio das letras se fazia em função de um público que tinha um lugar social determinado: 
Desde então os romancistas e os escritores só empregaram nas suas composições o segredo de aguçar apetites grosseiros, e excitar a curiosidade vulgar. Tratava-se de fazer descer a poesia do celeste cume que habitava para a colocar no nível dos assinantes [...]. Em lugar de se dirigirem à flor das inteligências somente se dirigiram aos instintos da multidão, não para os corrigir, mas para os satisfazer e lisonjear. A literatura foi posta ao alcance dos tendeiros; não se entenda por isto que não estimamos esta gente honesta, Deus o não permita! Unicamente não pensamos que a literatura deva descer até eles, quando eles não podem elevar-se até a literatura. [...] Deste modo o bom acolhimento de uma obra que tinha a sua origem nas classes elevadas, a passou a ter nas inferiores, a começar de baixo para cima, em lugar de ser de cima para baixo [...]. Falou-se a linguagem própria dos mercados, e algumas vezes a das galeras. (Correio Mercantil, 09 de outubro de 1848).

Fundado sobre este público, desenvolvera-se o comércio das letras, que degradava as obras de imaginação, ao mesmo tempo em que enriquecia as mediocridades, os "talentos miseráveis", que em sua paixão pelo lucro transformaram a república das letras em "um ajuntamento de industriosos, de comerciantes, e de especuladores". Perdera-se a pureza do trabalho literário, reduzido a mera mercadoria, ao passo que o homem de letras se reduzia a mera força de trabalho:

[...] continua a trabalhar, escravo, e produz: a história está principiada, o periódico espera a continuação amanhã; é inexorável, e não permite descanso; é preciso continuar, é preciso produzir, é preciso que o assinante tenha no dia seguinte seis ou nove colunas de emoções, é preciso, certamente, sempre e sem cessar, entreter com abundantes manuscritos esta goela devoradora. [...] Alguns, não podendo desempenhar esta tarefa, tiveram a feliz idéia de estabelecer uma manufatura de novelas e romances. [...] Chegar-se á a inventar máquinas de vapor, que darão folhetins a cada minuto. (Correio Mercantil, 09 de outubro de 1848).

Essa conjugação da degradação da arte e do gosto com a incorporação de um público de extração social inferior tinha seu corolário na ameaça de uma degradação moral sob o efeito dos romances. Introduzindo-se nos lares, o folhetim se tornara "a distração da manhã, e a recreação da noite, ele passa de mão em mão, é o amigo da família”. Dessa maneira, toda uma geração estaria recebendo sua educação moral da leitura dos "Mistérios de Paris, os Mistérios da Rússia, os Mistérios de Londres, e outras obras”, que ultrapassavam barreiras de classe, pois "quando os amos o têm lido, os criados e as criadas se apoderam dele e o saboreiam". Diante da ameaça moral representada pelo folhetim, e prevendo que em dez 
anos toda a França saberia ler, o redator chegava a concluir que teria sido melhor não existir tamanho público leitor para colocar-se sob a influência dos romances:

\begin{abstract}
Nós estamos longe de pretender exagerar como alguns espíritos melancólicos que não receiam atribuir aos romances todos os crimes que são julgados no tribunal de Assises, todavia não poderemos negar que a literatura seja uma influência viva, o romance sobretudo, e sobretudo o romance-folhetim, pela grande facilidade que tem de introduzir-se por baixo de todas as portas e de chegar a todos os sobrados. Por isto é de razão que nos assustemos à vista dos germes de destruição de que está impregnado este mau vento de publicidade. [...] Não se vos poderia dizer também que teríeis obrado muito melhor em deixar ao povo a sua santa simplicidade e a sua primitiva ignorância? (Correio Mercantil, 09 de outubro de 1848).
\end{abstract}

Embora não fosse comum encontrar testemunho tão eloqüente, sua análise da natureza e efeitos do romance não parecia constituir uma exceção, como se pode concluir da leitura de uma correspondência publicada tempos depois no Correio Mercantil, na qual o leitor manifestava sua indignação diante da publicação do breve romance $A$ sobrinha do cônego nos folhetins do Jornal do Commercio. Segundo o leitor anônimo, que se designava apenas como "O Católico Romano", sua indignação tinha origem na maneira como o clero era representado no romance, que conspurcava uma "classe tão respeitável" e, em sua manifestação, o correspondente dava mais um testemunho sobre a crença no poder do romance que povoava a imaginação desses letrados. Vendo no cônego do romance uma personificação da volúpia, o leitor sugeria ironicamente ao "ilustre romancista brasileiro" que ele fizesse o mesmo com os demais níveis da hierarquia eclesiástica, percorrendo toda a "escala dos pecados mortais"; com isso, ele acreditava, "ganharia a palma ao próprio Eugenio Sue, exímio autor dos mistérios de Paris". Mas, a seguir, deixando de lado a ironia, pedia ao romancista que empregasse seu talento "em objetos que moralizem o nosso povo, que necessita ainda mais de educação moral do que do pão quotidiano", e interpelava-o:

Ignora o nobre romancista de que para muita gente a leitura do folhetim é mais do que a de um livro de dogma? Não vê o perigo de tomar-se a ficção pela realidade? Muitas pessoas conhecemos nós que não têm outra noção dos Jesuítas senão a que lhes deu o Judeu Errante, e estão tão inabaláveis em suas convicções como um maometano nas doutrinas do seu falso profeta. (Correio Mercantil, 05 de dezembro de 1850).

Meses antes dessa correspondência, o Correio Mercantil iniciara a publicação de um novo folhetim de Sue, Os mistérios do povo, mas não sem antes justificar-se perante os 
leitores pela iniciativa que a alguns devia parecer arriscada. Segundo dizia o redator do Correio, ao chamar a atenção dos leitores - "especialmente a dos apaixonados da leitura de folhetins" - para a publicação que se iniciava, ele já tinha em mãos o romance havia dois meses, quando então um artigo traduzido do Times e inserido no Jornal do Commercio "reteve a nossa sofreguidão":

Entendemos que cumpria-nos primeiro examinar escrupulosamente o original que possuíamos, e sobre o qual somente assentava a mencionada crítica, porque nos não aventurássemos, a ser eco de princípios subversivos, máxime se pudessem eles ter aplicação ao nosso país. (Correio Mercantil, 13 de maio de 1850).

Não seria de todo implausível imaginar que a publicação tão oportuna de uma crítica a Sue no Jornal do Commercio, justamente quando o Correio Mercantil se preparava para dar a público o novo folhetim do "favorito escritor", fazia parte de uma estratégia de concorrência entre os periódicos. Mas o fato é que o Correio se viu obrigado a responder nos mesmos termos, eximindo-se de qualquer intenção subversiva, não sem antes desqualificar a publicação do colega. Segundo o redator, o correspondente do Times, traduzido pelo Jornal, não teria lido o romance criticado, baseando-se apenas em outro artigo que saíra em fevereiro na Revue des deux mondes, "porque até copiaram as mesmas palavras". E os redatores da Revue, segundo a opinião do Correio, eram "pela maior parte ou aristocratas encanzinados, ou criaturas aferradas à gente do regime que galgou o poder subindo pelas barricadas de julho de 1830".

Nesse caso, tratava-se de um artigo assinado por Charles de Mazade que discutia publicações recentes à luz da íntima conexão existente entre o pensamento literário e o desenvolvimento social. Com a mira sobre a recente revolução de fevereiro de 1848 - "dois anos se passaram desde que o turbilhão de um dia de inverno nos lançou ao desconhecido" e buscando identificar seus efeitos, Mazade negava a existência de quaisquer sinais de vitalidade no presente, embora fosse de esperar que, "como todos os movimentos profundos e justos", a revolução fizesse emergir o talento de escritores, oradores e artistas (MAZADE, 1850 , p. 902). A razão se encontraria na própria natureza dessa revolução, guiada pela idéia de democracia, "lei invencível do século XIX"; o triunfo do princípio democrático, acontecendo antes que uma "regra ideal" ou um "pensamento superior" viessem fecundá-lo, teria como conseqüência o aparecimento de "uma paixão furiosa e cega do nivelamento, uma energia assustadora e infelizmente vitoriosa de dissolução" (MAZADE, 1850, p. 904). E na relação entre o avanço da democracia e a produção literária do momento Mazade localizava o surgimento de obras como a de Eugène Sue: 
Compreendeis agora como esse movimento de fevereiro, última e gigantesca explosão do instinto democrático deixado a si mesmo, não produziu nem uma grande idéia, nem um caráter eminente, nem uma obra literária digna de nota; por que ele não deu à luz senão destruidores, sofistas e incapazes [...]; por que também, nas letras, não fez nascer nada que sobressaia, nada de vitorioso, e está reduzido ainda hoje a encontrar sua mais fiel expressão em obras como o livro novo do Sr. Sue: - os Mistérios do Povo -, onde eu não sei o que está mais ausente, se a originalidade, a retidão moral ou o gosto!" (MAZADE, 1850, p. 905).

A última produção de Sue forneceria, segundo Mazade, a idealização das loucuras revolucionárias que se ocultavam sob o nome de socialismo, "o ódio, a inveja e a difamação em estado bruto e grosseiro" (MAZADE, 1850, p. 911). Era o socialismo a fantasia à qual Sue identificaria o propósito de seu livro, "a reconciliação do povo e da burguesia", o que Mazade via sob um ângulo invertido:

[...] o sentido dos Mistérios do Povo não é um enigma: é sempre o pensamento da divisão da sociedade em duas classes irreconciliáveis que o autor chama, segundo o costume, os oprimidos e os opressores; as palavras importam pouco; - é a tradução, um pouco menos franca, dessa terrível sentença recolhida nos manuscritos de Robespierre: "Quando o interesse dos ricos será confundido com o do povo? Jamais!" O livro do Sr. Sue não tem outro sentido que o de reproduzir este antagonismo, de dar-lhe o interesse da ficção romanesca [...]. Este antagonismo tradicional, sempre vivo no dizer do Sr. Sue, tem suas personificações contemporâneas nos Mistérios do Povo, cuja fábula se abre às vésperas de fevereiro, na hora em que vai recomeçar a luta entre os vencidos e os vencedores, e, pode-se imaginar, os vícios e as virtudes são bem desigualmente repartidos. (MAZADE, 1850, p. 911-912).

Para Mazade, a corrupção do gosto, de que dava exemplo o livro de Sue, se relacionava diretamente com o princípio da soberania popular, em nome do qual a arte se rebaixava, tornando-se cúmplice de suas fraquezas e paixões; o escritor então se equiparava a um mercador de bebidas, que lucrava com a embriaguez do povo (MAZADE, 1850, p. 914). Dada a relação entre todos os fenômenos de uma época, esse declínio moral era acompanhado do desenvolvimento do materialismo, que levava, por fim, "ao reino do espírito de indústria"; a busca do ganho aparecia, então, como "um dos mais ativos dissolventes do princípio literário":

O que se tornou a arte, deixada a essa outra influência, sem força para lutar contra esse conjunto de causas aviltantes? Tornou-se uma indústria da qual se tem sobrevivido, que se tem explorado, aperfeiçoado, que pôde dar a um homem uma certa superfície 
comercial, como dizia antigamente o autor da Comédia Humana. Confundida, por uma invencível assimilação, na multidão dos ofícios vulgares, a arte participou de suas condições, contraiu suas preocupações e seus costumes [...]. O que são hoje os Mistérios do Povo, senão uma especulação, audaciosa e habilmente agenciada, sobre o furor popular? [...] Também o escritor quis um dia se chamar um trabalhador, e propagou-se no mundo ideal do pensamento essa idéia materialista de uma espécie de "direito ao trabalho" literário análogo ao "direito ao trabalho" industrial [...]. (MAZADE, 1850, p. 916).

Assim, todos os vícios da democracia haviam passado para as letras; começando pela transformação da arte em ofício e pela assimilação da inteligência à indústria, a democracia tivera na literatura um efeito semelhante ao que se vira na sociedade, destruindo "a aristocracia do espírito, a idéia de distinção e de hierarquia nas letras". Era o gênio literário equiparado a uma excrescência feudal ou ao capital desafiado pelo nivelamento democrático (MAZADE, 1850, p. 917).

Ao ler esse artigo da Revue des deux mondes, o redator do Correio Mercantil ressaltava seu viés político para desqualificá-lo como crítica literária, uma vez que o romance de Sue que ele começava a publicar destacava-se justamente por suas virtudes artísticas, não por seus princípios democráticos, tratando-se de uma "composição moderníssima e de gênero novo, em a qual a política antiga e a dos nossos dias aparecem matizadas com as mais lindas e tocantes descrições da vida social e doméstica. Aí o amor da pátria e o amor da família sobressaem de mãos dadas". Mas o que talvez se afigurasse tão ou mais importante do que essas qualidades, fazendo que ele, redator, declarasse ter a consciência tranquila ao publicar em folhetim a tradução dos Mistérios do Povo, era o fato de achá-los "muito interessantes e de modo algum aplicáveis ao nosso país, onde há só duas classes distintas - dos senhores e dos escravos" (Correio Mercantil, 13 de maio de 1850).

Dois anos mais tarde, como vimos, Manuel Antonio de Almeida apresentaria jocosamente o seu romance aos leitores do Correio como algo próximo a uns Mistérios do Rio de Janeiro - e o percurso traçado até aqui torna ainda mais sugestiva a brincadeira, quanto aos significados que poderia assumir para o autor ou para seus leitores. Afinal, o que Almeida fazia era também uma maneira de aclimatar o tal gênero moderníssimo e novo, trazendo de Paris e Londres para as ruas da Corte as descrições da vida doméstica e social. Mas, curiosamente, o que menos se via em tais descrições eram justamente aquelas "duas classes distintas - dos senhores e dos escravos", únicas capazes de despertar os escrúpulos do redator do Correio diante da ameaça de princípios subversivos. "Curiosamente" talvez não coubesse a essa constatação, quase indicando a expectativa daquilo que Almeida deveria ter escrito - o que não é nossa intenção, obviamente. Mas o fato é que o percurso ao longo do qual a crítica atribuiu diferentes sentidos ao romance manteve-se em torno de um núcleo que poderia ser sintetizado no problema do realismo, a verdade de sua representação (ANDRADE, 1974; CANDIDO, 1970; VERÍSSIMO, 1978). 
Dessa maneira, por diversos que fossem os sentidos da realidade que a crítica associava ao romance de Almeida, fechava-se a possibilidade de pensar das Memórias de um sargento de milícias aquilo que o redator do Correio Mercantil pensava dos Mistérios do Povo, que não podia dizer respeito a um país onde as únicas classes eram as de senhores e escravos. $\mathrm{E}$ assim, apagavam-se as marcas dos sentidos que podiam estar disponíveis aos seus primeiros leitores. Algumas dessas marcas tentaremos distinguir no próximo item.

4.

Voltemos alguns passos para lembrarmo-nos do folhetinista do Jornal do Commercio que indignava o correspondente do Correio Mercantil. O autor d'A Sobrinha do cônego, Joaquim José Teixeira, desde o ano anterior publicava pelo Jornal seus breves romances, assinados simplesmente por $\mathrm{T}^{2}$ Um desses folhetins, intitulado Novo Gil Braz (Original), contava a vida "não de um santo, que os não há mais, nem de um herói, que nos não lembramos dos nossos, porém de uma criatura que faleceu no exercício do honroso cargo de meirinho, ou, falando como o direito pátrio, de oficial de justiça" (Jornal do Commercio, 09 de setembro de 1849). Era um imigrante português chamado Braz Gadanho, que chegara sozinho ao Rio de Janeiro, aos doze anos, para trabalhar como caixeiro em uma loja. Além de sua parca bagagem, Braz trazia consigo as "palavras sacramentais de seu pai - Deus te abençoe, e trata de ganhar dinheiro"; pobreza e ambição que distinguiam não apenas Braz, mas também os outros "aventureirozinhos" com quem dividia a viagem rumo à fortuna:

Costumado com o seu pão de centeio e a sua sopa de toucinho e couves, não estranhou muito o tratamento de bordo; e demais, conquanto se lembrasse com saudade da terra e das manas, achava gosto em ver, pensando, já diante de si as árvores de patacas, e se entretinha em colher os dourados frutos para remeter alguns aos pais, e comprar com outros sua herdade e seu rebanho, assim como tinha o vizinho Matheus.

Entrava ainda a barra do Rio de Janeiro, e já daqui e dali o ouro lhe sorria: era o sol desenrolando sobre as rochas as lâminas fulgentes.

Não viam aqueles olhos senão dinheiro onde a natureza pôs grandeza e majestade! (Jornal do Commercio, 09 de setembro de 1849).

Tão logo desembarcasse, Braz logo veria diante de si o que o aguardava - não as árvores de patacas, mas "o caminho que levavam todos", o aprendizado em uma loja, trabalhando e apanhando dos caixeiros, enquanto contava ele próprio vir a tornar-se um dia

${ }^{2}$ Segundo Sacramento Blake, Joaquim José Teixeira publicou em 1876 um volume intitulado Romances, contendo "Mattaescura, publicado em folhetim do Jornal do Commercio em 1849; Angelica; As aventuras de Braz; A sobrinha do cônego, também publicado no Jornal do Commercio". Apesar da diferença no título, trata-se provavelmente do mesmo texto, visto que os demais enumerados foram publicado com a mesma assinatura T. empregada no Novo Gil Braz. (BLAKE, 1898, p. 179-180). 
caixeiro. Demitido da loja, Braz logo se arrumaria como marujo num navio que largava para a África, mas ainda não seria aí que encontraria a fortuna:

\begin{abstract}
Que bom negócio foi esse de açougue de carne humana, e como se há tornado excelente! Mas se, nesta época de moralidade em que vivemos, o carniceiro, conquanto lucre mais, está na rigorosa obrigação de pagar bem a quem o serve, quer conduzindo a manada, quer guardando-a no pasto, e quer livrando-a dos vermes, assim não acontecia quando se foi o tal navio, e os vaqueiros recebiam limitadas soldadas, e apenas de quebra alguma febre. (Jornal do Commercio, 09 de setembro de 1849)
\end{abstract}

Ao fim dessa viagem, portanto, de novo desocupado, Braz acabaria recrutado quando gastava o tempo a filosofar no morro do Castelo. Achando bela a vida militar, mas só quando vista de uma sacada, logo desertaria e deixaria a Corte, calhando de chegar a uma vila do interior no momento em que morrera o mestre de primeiras letras do lugar. Pôs-se então Braz a ensinar, tendo herdado do falecido livros, palmatória e óculos, até perceber as vantagens do ofício do rábula seu vizinho, o que o levou a mudar-se novamente, apresentando-se em seu novo destino como doutor de Coimbra. Tanta admiração causou a sabedoria do novo advogado, que jamais negava "razão a quem a queria ter", que o juiz ordinário lhe ofereceria a mão de sua filha, acompanhada de um bom dote. Como, porém, no mesmo dia ele soubesse da fuga de sua noiva com o arreiador da casa, além da intenção que tinham de assassiná-lo por causa de uma demanda a seu cargo, "perdeu o gosto pela vida do foro" e resolveu mudar-se novamente, iniciando a carreira de médico. Com banhos e clisteres o novo médico fazia milagres, até que a morte de uma paciente lhe fez perder toda a clientela. Valeu-lhe então conhecer alguém que tinha relações suficientes para nomeá-lo escrivão de órfãos e tabelião, o que lhe permitiu levar vida de príncipe à custa dos bens dos órfãos e das propinas dos herdeiros. Mas como naquela época "os ofícios de justiça eram então dados como as terras a fidalgos ou a seus protegidos para que deles ou delas tirassem proveito sem trabalho", Braz perdeu seu cartório para alguém cujas relações chegavam à Corte. Fez-se então taverneiro, negócio no qual empregou as propinas recebidas, mas que se perdeu em um incêndio. $O$ mesmo protetor lhe arranjou então um emprego de carcereiro, vago "porque o número dos que a ele se atiravam, e muito mais o enxame de patronos, embaraçava a escolha". No novo emprego Braz ia "cobrando seus tributos sobre a importação de bebidas espirituosas, sobre os passeios noturnos, etc.", até que a doença fizesse com que médicos e boticários lhe aliviassem do peso das algibeiras. Foi assim que, contando uns 50 anos de idade, Braz resignou-se a um cargo de meirinho exercido honestamente, ou "sem aquela habilidade tantas vezes desenvolvida por ele".

A princípio, o aparecimento desse folhetim não se destacaria por nenhum evento particular, visto que não motivou os protestos de um único leitor católico, como A sobrinha do cônego, nem jamais superou o anonimato do rodapé em que nasceu. Mas nele se 
cruzavam elementos a partir dos quais podemos vislumbrar um pouco da rede de interlocuções na qual se formava a cultura literária do período. E o primeiro desses elementos é necessariamente o título, Novo Gil Braz, referência direta ao Gil Blas, que o inspirava. A História de Gil Blas de Santillana fora publicada entre 1715 e 1735 por Alain René Le Sage. Filho de pequenos proprietários, Gil Blas é enviado à Universidade de Salamanca, onde nunca chegará, desviado por uma seqüência de acontecimentos que o envolvem, levando-o a assumir uma série de papéis, desde criado de uma quadrilha de ladrões até secretário de um ministro, situação em que ele decide enfim encerrar suas aventuras, retirando-se para suas propriedades e para a vida pacata de quem acredita piamente ser pai de seus filhos.

Traduzido para o português por Bocage já no final do século XVIII, Gil Blas se tornaria uma referência familiar aos leitores do Rio de Janeiro, sendo o romance que permaneceu por mais tempo anunciado nas páginas do Jornal do Commercio, bem como um dos mais solicitados pelos consulentes da Biblioteca Nacional, inclusive no ano em que Teixeira publicava o seu Novo Gil Braz (MANÇANO, 2010; ROCHA, 2011). Dessa maneira, a opção de Teixeira ao incluir no título a referência ao romance do século anterior oferecia ao leitor uma chave de leitura que estabelecia ao mesmo tempo a sua interlocução - no caso, revelando que a maneira como aqueles sujeitos vivenciaram a literatura passava por caminhos próprios, e que a prática dos leitores não se limitava a enquadramentos nacionais ou de época, podendo ser experimentadas como contemporâneas leituras de obras muito distantes no tempo e no espaço. Talvez pareça que com isso se quer reabrir a discussão sobre a caracterização das Memórias como romance picaresco, mas não é esse o problema que está se delineando aqui. Se o Novo Gil Braz pode iluminar de alguma maneira a leitura das Memórias de um Sargento de Milícias que veriam a luz três anos depois, é por revelar a possibilidade de uma ligação direta entre o diálogo literário a partir do qual o romance se construía e o debate público contemporâneo no qual intervinha, elaborando o seu sentido político no interior de sua opção formal. E essa intervenção ficava muito clara nos parágrafos finais do folhetim de J. J. Teixeira, que coroava a assimilação de seu personagem aos meios honestos de vida com uma moralidade que fazia o elogio dos portugueses emigrados:

O herói cujos feitos acabamos de relatar devera ter começado a sua carreira nesta época de luzes; porque, industrioso como era, outros meios acharia ele mais seguros de enriquecer em pouco tempo, vindo a merecer assim muitas cortesias na vida e muitas seges na morte.

Felizmente a grande maioria daqueles que para cá nos mandava a metrópole preferiram aos meios torpes de adquirir fortuna o trabalho honesto e produtivo, tornando-se assim dignos do respeito de seus filhos brasileiros e dignos das bênçãos da pátria adotiva. (Jornal do Commercio, 09 de setembro de 1849). 
Apesar de a narrativa fazer referência a um passado indefinido - "aquela idade de ouro", "aquela idade de inocência", quando "não se tinha a malícia antes da barba" -, seria claro para o seu leitor que a história de Braz Gadanho recomeçava todos os dias em cada menino português que cruzava o oceano para trabalhar como caixeiro e se contava não no folhetim, mas em poucas e repetidas linhas na página de anúncios dos jornais (Jornal do Commercio, 20/07/1849; 11/09/1849; 19/09/1849; 11/09/1849; 15/09/1849; 16/09/1849). Por isso mesmo, era da maior relevância para aquele folhetim que o destino individual de Braz convergisse para o mesmo "trabalho honesto e produtivo" que caracterizaria a maioria dos emigrados, sobretudo naquele momento, em que a ficção parecia oferecer um final feliz tanto para o personagem enfim moralizado quanto para todos seus compatriotas, enfim apaziguados com seus filhos brasileiros e sua pátria adotiva após um período especialmente conflituoso (CANO, 2007). Relegando ao passado e a uma minoria de imigrantes os "meios torpes de adquirir fortuna", Teixeira dava uma moralidade conciliadora ao seu escrito, publicado logo após as comemorações da Independência.

Almeida, por sua vez, ao dar relevo ao mesmo elemento da nacionalidade dos personagens em seu romance publicado, indicava, por um lado, que três anos depois essa questão ainda se mantinha significativa para um público leitor socialmente determinado por uma rede de interlocução mais ampla. A diferenciação entre brasileiros portugueses surgia desde o primeiro capítulo, na descrição da festa de batizado do Leonardo filho, quando "os convidados do dono da casa, que eram todos d'além mar, cantavam ao desafio, segundo seus costumes; os convidados da comadre, que eram todos da terra, dançavam o fado" (Correio Mercantil, 27/06/1852). Logo na seqüência, essa diferenciação seria reforçada na cena em que o Leonardo pai cantava uma "modinha pátria" inspirado "nas saudades da terra natal", como era "natural a um bom Português que o era ele". A cena ganhava um toque de humor por seus versos bem pouco líricos, mas também por um detalhe suprimido na versão em livro: uma dicção própria do emigrado que o aproximava da imagem caricatural do "galego", carregada de significados políticos nos momentos em que aflorava a tensão antilusitana:

Quando estaba em minha terra

Acompanhado sozinho,

Cantaba de noite e de dia

Ao pé d'um copo de binho! (Correio Mercantil, 27 de junho de 1852).

O mesmo tom simpaticamente divertido serviria novamente para caracterizar o meirinho e sua comadre a partir da distinção entre nativos e emigrados; na passagem em que se revelava a intenção da comadre de casar sua sobrinha com Leonardo, ela aproveitava as infidelidades da cigana, que aquele tinha por amante, para se por em ação: 
- Pois, compadre, disse-lhe ela, você não se emendou ainda?...

- Qual, história, sou doudo por estas cousas...

- Mas, homem, você não se tem dado bem nem com as ilhoas nem com as ciganas; para que antes não procura uma filha cá da terra...

[...]

- Nada, não gosto desta gente...

- Não tem razão; há por aí muita rapariga capaz; é verdade que o que elas querem é o toma lá dá cá debaixo do arco cruzeiro.

- É por isso mesmo que eu não gosto. (Correio Mercantil, 19 de setembro de 1852).

Mas o que continha certa leveza na figura do Pataca ganhava matizes mais fortes na medida em que outros personagens surgiam na história. Era o caso de um dos antagonistas do menino Leonardo em suas peraltices infantis, o mestre de cerimônias, cuja descrição dava ênfase à sua condição de português, lado a lado com sua caracterização moral, da qual sobressaía a duplicidade, a hipocrisia e o vício:

O mestre de cerimônias era um padre de meia idade, de figura menos má, filho da Ilha Terceira, porém que se dava por puro Alfacinha: tinhase formado em Coimbra; por fora era um completo S. Francisco de austeridade católica, por dentro refinado Sardanapalo, que podia por si só fornecer a Bocage assunto para um poema inteiro; era pregador que buscava sempre por assunto a honestidade e a pureza corporal em todo o sentido; porém interiormente era sensual como um Oriental. (Correio Mercantil, 29 de agosto de 1852).

Um segundo antagonista de Leonardo, esse na sua fase adulta, seria o mestre de reza, responsável por impedir seu casamento com Luizinha, e que se define a partir da origem portuguesa: "Meus pais eram Algarves, e eu não quero desmentir a minha paternidade" (Correio Mercantil, 30/01/1853). Pode-se verificar, então, uma recorrência na caracterização de personagens a partir de sua origem nacional e também uma coerência quanto à função que esses personagens desempenham no enredo. Isso não basta, porém, para afirmarmos a existência de uma estrutura dualista, dentro da qual brasileiros e portugueses se distinguissem moralmente ou que o herói do romance, que era da terra, enfrentasse regularmente os obstáculos à sua felicidade criados por personagens d'além-mar. Mas o que talvez tornasse ainda mais significativa a presença dos personagens portugueses no romance, diluindo a tensão inerente ao tema, era o fato de dissociar todos esses personagens da figura que era mais frequentemente associada ao "galego" e ponto de convergência das demandas sociais, o caixeiro. Dessa maneira, as Memórias constituíam um passo adiante no movimento de distensão já sinalizado pelo Novo Gil Braz, na medida em que dispensava a moralidade positiva deste, desnecessária quando já não havia nelas nem os sinais que 
evocavam a tensão latente no cotidiano dos leitores. Pois se esse movimento de distensão dialogava com o universo de referências disponíveis, estava longe de pretender refleti-las. No próprio Correio Mercantil vinha à tona a questão da imigração portuguesa, às vezes de maneira inesperada, como na correspondência de um colaborador que se assinava Dr. Jão Burrúncias e fazia a defesa da construção de estradas de ferro por companhias inglesas. Argumentando não haver alternativa aos ingleses para essa tarefa, Burrúncias lembrava, numa ironia marcada de itálicos, que

[...] os nossos amados irmãos portugueses, logo que aportam às nossas praias, não querem outro meio de vida senão o de caixeiro de loja ou de taverna, onde fazem o seu tirocínio com a mira (aliás muito louvável) no comércio a retalho que lhes pertence exclusivamente. [...] $\mathrm{E}$ fazem muito bem, pois se eles têm o comércio a retalho, que lhes abre os braços tão vantajosamente, por que se hão de ocupar em trabalhos que são tão penosos? (Correio Mercantil, 08 de julho de 1852).

No dia seguinte, o doutor teria a resposta de um correspondente assinado Cosmopolita, que ressaltava justamente o fato de trazer, a propósito de estradas de ferro, a questão do comércio a retalho, já tão debatida, "porém que de vez em quando fazem ressuscitar como para perpetuar a aversão e ódio dos nacionais contra os portugueses" (Correio Mercantil, 09 de julho de 1852). Burrúncias ainda voltaria a se manifestar brevemente, indignado contra a acusação, mas o fato é que "ilação tão odiosa" devia estar ao alcance de qualquer leitor. E na medida em que Almeida dissociava seu romance de qualquer vínculo com os sinais mais evidentes da tensão antilusitana, ele evitava também que aflorasse um de seus mais delicados aspectos, que ia muito além da ideia de nacionalidade, caracterizando os portugueses por sua posição social, pois o que tornava politicamente significativa a questão do comércio a retalhos era o fato de abrir aos portugueses um meio de enriquecimento que não seria acessível aos nacionais, atrelando-se assim aos termos da nacionalidade uma diferenciação de classes, já que os brasileiros estariam fadados à miséria enquanto os portugueses ostentariam "riquíssimas propriedades, esplêndidas mobílias, carros, luxo asiático, condecorações, dignidades" ( $O$ Grito Nacional, 01 de julho de 1852), tendo chegado "de tamancos e caixa de pinho" (O Grito Nacional, 15 de agosto de 1852).

Nesse sentido, o caminho apresentado pela narrativa de Manuel Antonio de Almeida distanciava-se tanto dos elementos que poderiam associar-se à temática antilusitana quanto dos seus desdobramentos socialmente mais perigosos, sem que, no entanto, saísse de seu foco central a questão da propriedade. Enquanto Joaquim José Teixeira encontrava uma solução moralizante para a história de seu Braz Gadanho - desde a miragem da árvore de patacas até sua conformação ao trabalho honesto -, as Memórias traziam a questão da propriedade dissociada de qualquer moralidade e, sobretudo, de toda distinção que se traduzisse em termos de oposição de classes. 
A trajetória de Leonardo, que o leva da ilegitimidade do "filho de uma pisadela e de um beliscão" à respeitabilidade do pater famílias, passa necessariamente pela propriedade, da qual ele nunca esteve propriamente apartado, mas que lhe dá acesso ao final feliz. A ilegitimidade, a rigor, não encontrava um lugar social definido, difundindo-se as relações irregulares entre personagens de diferentes extrações e precedendo, inclusive a origem do próprio Leonardo. Como vimos, a vinda de sua mãe ao Brasil fora motivada pela ligação com o filho de um militar do círculo próximo ao rei, o que só podia resultar em sua desonra, dada a impossibilidade de repará-la por meio de casamento tão desigual. A situação, porém, não impede que Maria venha a estabelecer outra relação informal, mas relativamente estável, com Leonardo Pataca, até sua fuga com o capitão de um navio que partia para o reino. Posto fora de casa por seu pai, o rapaz encontraria o núcleo de personagens em torno de Vidinha, composto por "duas irmãs, ambas viúvas, ou que pelo menos diziam sê-lo, uma com três filhas e outra com três filhos". Uma dessas filhas era Vidinha, "solteira como uma de suas irmãs: a última era também solteira, porém não como estas duas" (Correio Mercantil, 23 de janeiro de 1853). Da mesma maneira, as ligações fortuitas e informais permanecem como possibilidade aberta ao núcleo de personagens que se situam acima de Leonardo, como é o caso do major Vidigal, que troca a liberdade do rapaz vadio pela união com Maria Regalada. O que se tornará decisivo na sua trajetória é, sim, o que lembra a comadre nas duas ocasiões em que tenta defender o afilhado: primeiro, diante de Leonardo Pataca - "Oh! Mas isto não pode ser assim; correrem com o rapaz de casa para fora!... Ele não é nenhum desgraçado, pois sempre tem o que lhe deixou seu padrinho" (Correio Mercantil, 16 de janeiro de 1853) - e depois em casa do major:

[...] Isso não é razão, não, senhor, para se mandar tocar de chibata um moço que não é nenhum valdevinos; pois o senhor major bem sabe que o padrinho quando morreu deixou-lhe alguma cousa, que bem lhe podia estar já nas mãos, e ele por isso livre da maldita farda [...]. (Correio Mercantil, 10 de julho de 1853).

E, de fato, só ao entrar na posse da herança que lhe deixara o padrinho Leonardo pode enfim se casar com seu primeiro amor, dando ao romance o indispensável final feliz. Por outro lado, há um segundo elemento que se sobrepõe à regularidade das relações familiares e que é tão decisivo quanto o acesso à propriedade para o destino de Leonardo, o empenho ou compadresco, "mola real de todo o movimento social" (Correio Mercantil, 26 de junho de 1853, p. 1). Baseando sobre essa dinâmica as Memórias de um sargento de milícias, Almeida enredava seus personagens em uma mesma teia de prestações de favores que acabava por constituir um elemento unificador. A passagem de agregado a proprietário não extrapolava o domínio da família e qualquer conflito encontrava solução dentro da rede de proteção e compadresco em que todos se inseriam, e o acesso à propriedade e aos favores disseminados por toda a escala social, da maneira como eram representados por Manuel Antonio de 
Almeida, diluíam as contradições e apaziguavam as tensões dentro das quais se formava a experiência do público leitor.

Dessa maneira, a representação literária da "mola real de todo o movimento social" realizava uma seleção do elemento escolhido para sintetizá-la, construía engenhosamente um enredo sobre este elemento (de modo a obscurecer inclusive os defeitos de construção) e, principalmente, excluía todos os outros que poderiam, aos olhos de seus primeiros leitores, constituir um movimento tão ou ainda mais real que aquele. E talvez essa característica do romance possa ajudar a entender certa demora para que a crítica começasse a prestar atenção a suas qualidades de observação e verdade. Pois de fato nada disso estava ausente dele, mas dentro de uma perspectiva politicamente significativa, em que a própria apresentação da verdade, e não o seu ocultamento, servia para neutralizar os conflitos. Passado o momento político e perdida essa perspectiva, a fidelidade da cópia dos costumes impressionaria os leitores da posteridade, mas talvez tenha sido justamente tudo aquilo que não tinha lugar nessa cópia que permitia às Memórias de um sargento de milícias ocupar um espaço determinado, disputado àquelas histórias "de modo algum aplicáveis ao nosso país": uma versão aclimatada e segura de uns Mistérios do Rio de Janeiro.

\section{Referências}

ANDRADE, Mário de. Memórias de um sargento de milícias (1940). In: Aspectos da literatura brasileira. São Paulo: Martins, 1974.

BLAKE, A. V. A. Sacramento. Diccionario bibliographico brazileiro. Rio de Janeiro: Imprensa Nacional, 1898.

CANDIDO, Antonio. Dialética da malandragem (Caracterização das Memórias de um sargento de milícias). Revista do Instituto de Estudos Brasileiros, São Paulo, n. 8, p. 67-89, 1970.

CANO, Jefferson. A política da lusofobia: partidos e identidades políticas no Rio de Janeiro (1848-1849). Lócus: Revista de História, Juiz de Fora, v. 13, n. 1, jan./jun. 2007.

MANÇANO, Regiane. Livros à venda: presença de romances em anúncios de jornais. 2010. Dissertação (Mestrado em Teoria e História Literária) - Instituto de Estudos da Linguagem, Universidade Estadual de Campinas, Campinas.

MAZADE, Charles de. De la démocratie en littérature. Revue des Deux Mondes, Paris, t. 5, 1850.

ROCHA, Débora Cristina Bondance. Bibliotheca Nacional e Pública do Rio de Janeiro: um ambiente para leitores e leituras de romance (1833-1856). 2011. Dissertação (Mestrado em 


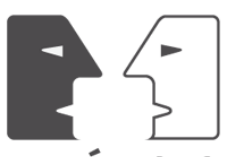

ANTÍTESES

Teoria e História Literária) - Instituto de Estudos da Linguagem, Universidade Estadual de Campinas, Campinas.

SAINTE-BEUVE, Charles-Augustin. De la littérature industrielle. Revue des Deux Mondes, Paris, t. 19, 1839.

UM BRASILEIRO. Memórias de um sargento de milícias. Rio de Janeiro: Typographia Brasiliense de Maximiano Gomes Ribeiro, 1855. Tomo II.

VERÍSSIMO, José. Um velho romance brasileiro. In: ALMEIDA, Manuel Antonio de. Memórias de um sargento de milícias. Rio de Janeiro: Livros Técnicos e Científicos, 1978. p. 124.

Jornal do Commercio, 1849

Correio Mercantil, $1848-1853$

O Grito Nacional, 1852 